\section{ポリブチレンテレフタレート $(\mathrm{PBT})$}

Polybutylene Terephthalate
豊岡 豊

Yutaka Toyooka
射出成形法を使用した PBT の用途拡大例について 報告する。

BS 放送受信用のパラボラアンテナのアームには従 来金属が使用されていた。意匠性, 生産性, コストダ ウンの要求から射出成形による樹脂化が計画され, 強 度, 寸法安定性, 而候性に優れるガラス繊維強化 PBT が検討された。パラボラアンテナは指向特性が

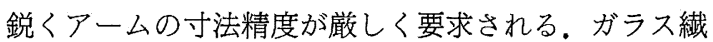
維 (GF) 強化樹脂は射出成形すると樹脂の流動する方 向に GF が配向し，樹脂自身の配向も加わり成形収縮 率が流動方向とその直角方向で異なる傾向を有してい る(図 1) ${ }^{1)}$. その異方性の程度は非晶性樹脂に比較し て結晶性樹脂が大きい. 成形収縮率の異方性が主原因 となり, 得られる成形品がその形状により複雑に反つ たり変形したりするので金型のキャビティ形状を正確 に転写しないという $\mathrm{GF}$ 強化結晶性樹脂の本質的な欠 点を有している．上字型をしたアームの角度等を希望 する設計範囲に収まるように製品形状や金型のゲート 配置等を検討し, 成形条件を最適化することで寸法精 度や L 字型の角度等がスペックを満足したアームが 製作可能となり実用化に到っている。

PBT の品質改良による用途拡大の例として耐加水 分解グレードの開発がある. PBT は高温, 高湿度下 でエステル結合が加水分解を起こし重合度が低下し強

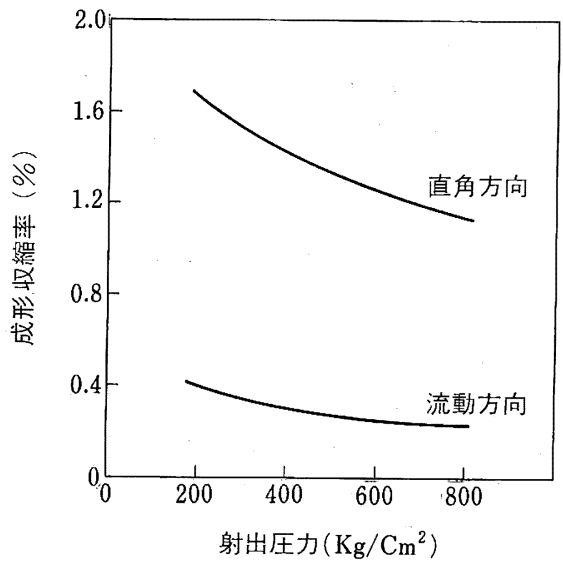

図 1 GF 30\% 入り PBT の成形収縮率と 射出圧力
度が大きく低下することが知られている 動車エンジンルーム内の温度が高くなる傾向があり, また自動車に塔載される電装部品の点数も増加してお り，高温，高湿下の環境に今まで以上に耐えることが できる PBT が求められている.PBT の加水分解反 応は末端のカルボン酸基が促進すると言われており末 端基をエポキシ化合物やオキサゾリン化合物で封鎖し たり，PBT 中の水分を制御することで加水分解を抑 制するという報告がある ${ }^{3)}$. 図 2 は当社耐加水分解グ レード（タフペット G $1030 \mathrm{~A}$ ），と一般グレード（同 G 1030）のプレッシャークッカーテストでの耐加水分 解性の比較である ${ }^{4)}$. G $1030 \mathrm{~A}$ が 3 倍程度耐加水分解 性が向上しており，自動車用のコネクターやリレーケ 一ス等に採用されている。

\section{文 献}

1) 三菱レイヨン (株) タフペット PBT 技術資料

2）湯木和男編：飽和ポリエステル樹脂ハンドブック，日 刊工業新聞社編 (1989) p.307

3）公開特許 特開昭 63-83123, 特開平 2-206567

4）三菱レイヨン（株）タフペット PBT 技術資料

(三菱レイヨン（株）豊橋開発研究所・主席研究員, 工博, 専門 $=\mathrm{ABS} \& \mathrm{PBT}$ 樹脂の改質）

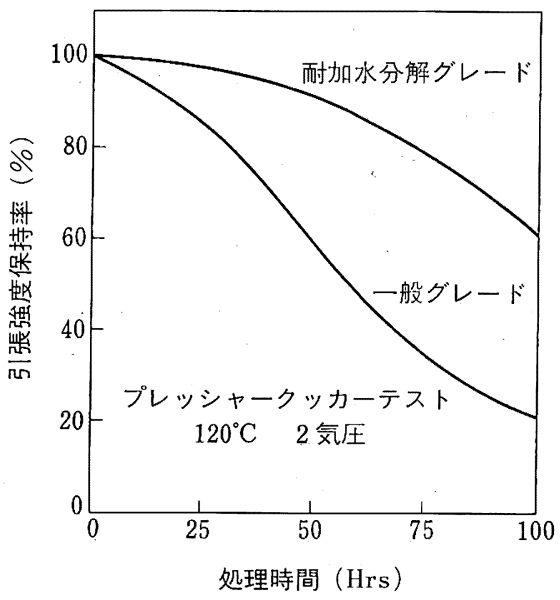

园 2 耐加水分解グレードと一般グレード の加水分解性比較 